\title{
INCREASINGLY SAFE, HIGH-ENERGY PROPULSION SYSTEM FOR NANO-SATELLITES
}

\author{
Lyubomyr Sabadosh*, Serhii Larkov**, Oleg Kravchenko***, Vladyslav Sereda**** \\ * Space Initiatives Center, NGO, 9, Boryspilska St., Kyiv 02099, Ukraine \\ ** Special Design Office, Kyiv Radio Plant, PJSC, 9, Boryspilska St., Kyiv 02099, Ukraine \\ *** Podgorny Institute for Mechanical Engineering Problems, 2/10 Pozharskoho St., Kharkiv 61046, Ukraine \\ **** National Aerospace University KhAI, 17, Chkalova St., Kharkiv 61070, Ukraine \\ lyubomyr.sabadosh@sic.org.ua; serge.larkov@sic.org.ua; krav@ipmach.kharkov.ua; v.sereda@khai.edu
}

\section{Summary}

Numerous attempts have been undertaken to develop propulsion systems for nano-satellite-type spacecrafts to enable their maneuvering in orbits. One of the potentially viable chemical propellant propulsion systems is a hybrid system. The present paper studies propellant composition variants with the metal hydride as fuel that can be chosen for a nano-satellite hybrid propulsion system. It defines key requirements for chemical propellant nano-satellite propulsion systems, and specifies potential propellant pairs based on a compact metal hydride. The study describes basic technical characteristics of a $1 \mathrm{U}$ CubeSat propulsion system.

Keywords: satellite propulsion, metal hydride, hydrogen peroxide

\section{INTRODUCTION}

A dramatic increase in the number of launched micro- and nano-satellites, first of all on the CubeSat platform [1], has triggered a self-sustaining process, i.e. the number of nano-satellite launches grows, so does the mass production of their subsystems, while the costs of a spacecraft development are decreasing. Hence, market entry barriers lower, this leads to the growth in the number of business establishments that get involved in production of their own spacecrafts.

Such satellites have a number of specific features, first of all limited capacities of their power supply systems, increased safety requirements due to cluster launches, highly unified design, and limited life time (usually about a year).

At present, the surpassing number of nano-satellites are not equipped for their maneuvering in orbits, however numerous attempts have been undertaken to develop an inexpensive, safe and effective propulsion system for nano-satellites. The use of electric rocket motors appears to be limited, as their 
power supply systems are of low capacity, and any increase in such capacities is constrained by the need for heat dissipation. Moreover, nowadays, due to their high acceleration, only chemical fuel-based motors can be used for orbit correction, orbit rendezvous etc.

The main task of the study is to analyze the opportunities for developing a hybrid propulsion system based on non-toxic and safe propellants for nano-satellites.

\section{COMPARATIVE ANALYSIS OF CHEMICAL PROPELLANT NANO-SATELLITE PROPULSION SYSTEMS}

\subsection{Mono- and bipropellant micro-sized liquid-propellant rocket engine}

For nano-satellites, there is a wide selection of cold gas propellant systems and monopropellant micro-sized liquid-propellant rocket engines. The use of high-concentrated hydrogen peroxide, nitrous oxide and new environmentally friendly composite monopropellants is a major trend in the development of nano-satellites propulsion systems. Their key disadvantage is a low specific impetus (no more than $2,500 \mathrm{~m} / \mathrm{s}$, on average $1,500 \mathrm{~m} / \mathrm{s}$ ), and explosion hazards, particularly in case of a high-energy monopropellant mixture.

The use of bipropellant propulsion systems is constrained by an increasingly complicated feed system and control of passive mass when a second component is supplied. The possible approach is to develop a bipropellant propulsion system based on hydrogen-oxygen, and produce components onboard of a spacecraft through water electrolysis [2], which can ensure a specific impetus of 3,043 m/s at a 0.28 propellant mass fraction.

\subsection{Use of micro-sized solid-propellant rocket motors for spacecraft control and as a cruise motor}

Solid propellants can be used for developing nano-satellites propellant systems in a few ways. Traditional micro-sized solid-propellant rocket motors of a 2,643 m/s specific impetus and a 0.65 propellant mass fraction [3] can serve as a starting point for analyzing various propulsion systems.

An array of MEMS-based solid-propellant rocket motors and those with electrically ignited propellants [4] can be used for long-term missions, but they have very poor mass characteristics.

\subsection{Development of nano-satellite hybrid propulsion systems}

Propulsion systems that are simpler than for monopropellant liquid rocket engine, with power characteristics higher than for solid-propellant rocket motors, that can be controlled and re-ignited, are thought to be right for nano-satellites.

Both the European Union, the US and Japan are intensively working on the development of hybrid propulsion systems, and in most cases, they use HTP and nitrous oxide as oxidizers. As combustive components, they use paraffin, polyethylene, HTPB. When using nitrous oxide as an oxidizer [5], the level of 2,648 m/s has been achieved. Further work is carried on to develop a hybrid propellant system with far high characteristics, and a specific impetus above $3,000 \mathrm{~m} / \mathrm{s}$ in order to implement interplanetary missions $[6]$.

Among other works in this area, the studies of the Warsaw Institute of Aviation [7] are worth acknowledging, as they provide extensive research in how to receive and use $98 \%$ hydrogen peroxide as an oxidizer for hybrid and liquid propellant rocket engines. 


\subsection{Development trends for nano-satellite propellant systems}

The authors suggest that the development of chemical propellant micro-sized propellant systems for nano-satellites will continue, first of all for performing orbital maneuvering that will require delta velocity of up to 300-500 m/s. The use of nano-satellites in deep space and, as the first step, for Moon research will require delta velocity of about $1000 \mathrm{~m} / \mathrm{s}$, and in the longer terms, up to $3000 \mathrm{~m} / \mathrm{s}$ to reach the lunar surface.

It is also necessary to note a specific feature of a propulsion system for nano-satellites, namely its increased passive mass which is caused by the following factors:

- faster volume reduction in comparison to reduction of area when linear dimensions are decreasing (square-cube law)

- for liquid components of propellant, it is impossible to provide proportional reduction of throat areas and physical dimensions of lock and control valves.

This suggests that nanosatellite orbital maneuvering could be successfully provided by existing green propulsion systems. In this case, for a typical specific impetus of 1,500-2,500 m/s a propellant load should make $20-30 \%$ of spacecraft mass. However, deep space missions require specific impulse of at least $3,000 \mathrm{~m} / \mathrm{s}$ and a propellant load of above $50 \%$, which makes the use of existing chemical propulsion units for deep space exploration nanosatellite quite problematic.

Hence, the authors conclude, chemical propulsion systems for nanosatellites should have the following key characteristics:

- high specific impetus (at least 3,000 m/s)

- mass fraction of components in a liquid or gaseous form should be minimized

- low combustion temperature that allows using radiation cooling rather then ablative cooling for chamber and nozzle structure (regenerative cooling is not considered).

\section{WAYS FOR BUILDING HIGH-ENERGY PROPULSION SYSTEMS}

\subsection{Brief review of existing and potential oxidizers}

Nowadays, high-concentrated hydrogen peroxide and nitrous oxide, as well as nitrogen-acid oxidizers are used as oxidizers for nano-satellites propulsion systems. The oxidizer, that has the highest energy, i.e. nitric tetroxide, can provide a specific impetus of about 3,000 m/s when using hydrocarbons, and up to $3,200 \mathrm{~m} / \mathrm{s}$ with hydrazine fuel. In case of using 'green' components, the energy efficiency of a propellant system for nano-satellites can reach a specific impetus of maximum $3,100 \mathrm{~m} / \mathrm{s}$.

\subsection{Hydrides and borohydrides as potential fuels for nano-satellites}

The use of metal hydrides and borohydrides can give a new impulse to the development of nano-satellite propulsion systems, especially when using hydrogen peroxide as an oxidizer. While having low enthalpy, metal oxides are a source of chemical energy, and emitted hydrogen provides high performance of expansion.

One of the highest energy propellant pairs, i.e. HTP and beryllium hydride, with the specific impetus of about 5,000 m/s was considered for the RD-560 engine under the Mars expedition project, but the research was put on halt because of the highly toxic beryllium compounds and the difficulties in 
producing a sufficient amount of hydride. Considering extreme toxicity of the beryllium compounds, the use of this metal has no prospects.

The use of borohydrides, both liquid and solid, is also constrained by their toxicity, however their derivatives, like alkaline metal borohydrides are widely applied, being quite toxic though (LD $50=56 \mathrm{mg} / \mathrm{kg}$ for sodium borohydride). Lithium hydride and lithium aluminum hydride are slight less toxic (LD 50=78 and $85 \mathrm{mg} / \mathrm{kg}$ ), and hydrides like aluminum hydride is low-toxic.

The hydrides that are being analyzed, are highly reactive and require a controlled setting for their processing, as well as additional safety provisions when building a propulsion system. At present, hydrides are studied as high-energy and hypergolic additives [9], [10].

The results of thermodynamic calculations for some propellant pairs with HTP as oxidizer (1 MPa chamber pressure, nozzle expansion ratio 100 , losses at a two-stage process are taken into consideration - Pic. 1) show that in comparison with hydrocarbon fuels, the use of lithium aluminum hydride and aluminum hydride:

- significantly reduces an optimum amount of the oxidizer in the fuel which has a positive impact on mass and dimension characteristics of a oxidizer feed system;

- makes a specific impetus of the propellant pair less susceptive to an oxidizer surplus ratio, and therefore to the quality of propellant processing;

- shows recovering properties of combustion products, with a hydrogen mole fraction of about $60 \%$.

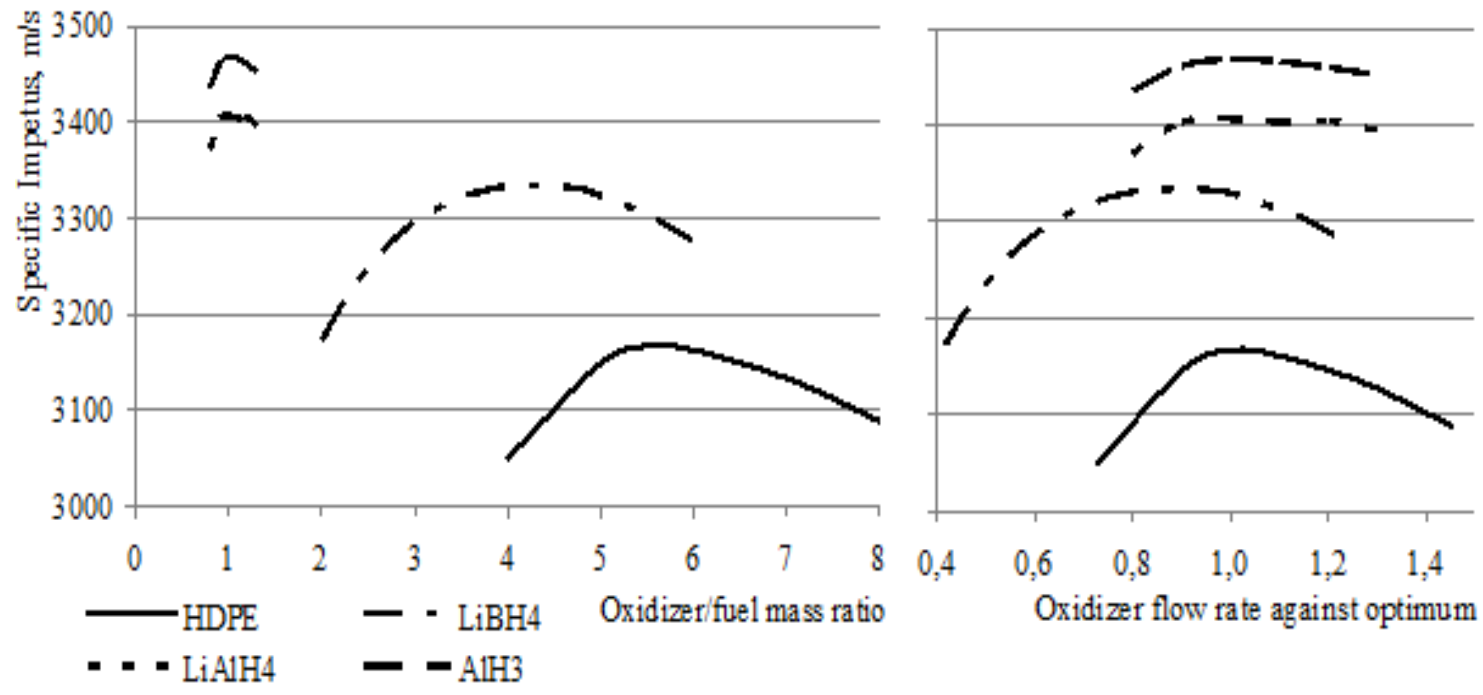

Pic. 1. Hydride-based propellant thermodynamic calculation results

It should be noted, hydrides can be used with both low concentration hydrogen peroxide (industrial grade), and pure water, with a specific impetus up to $2,960 \ldots 3,060 \mathrm{~m} / \mathrm{s}$ - see Pic. 2. In this case, it is recommended to use alkaline metals, like lithium. 


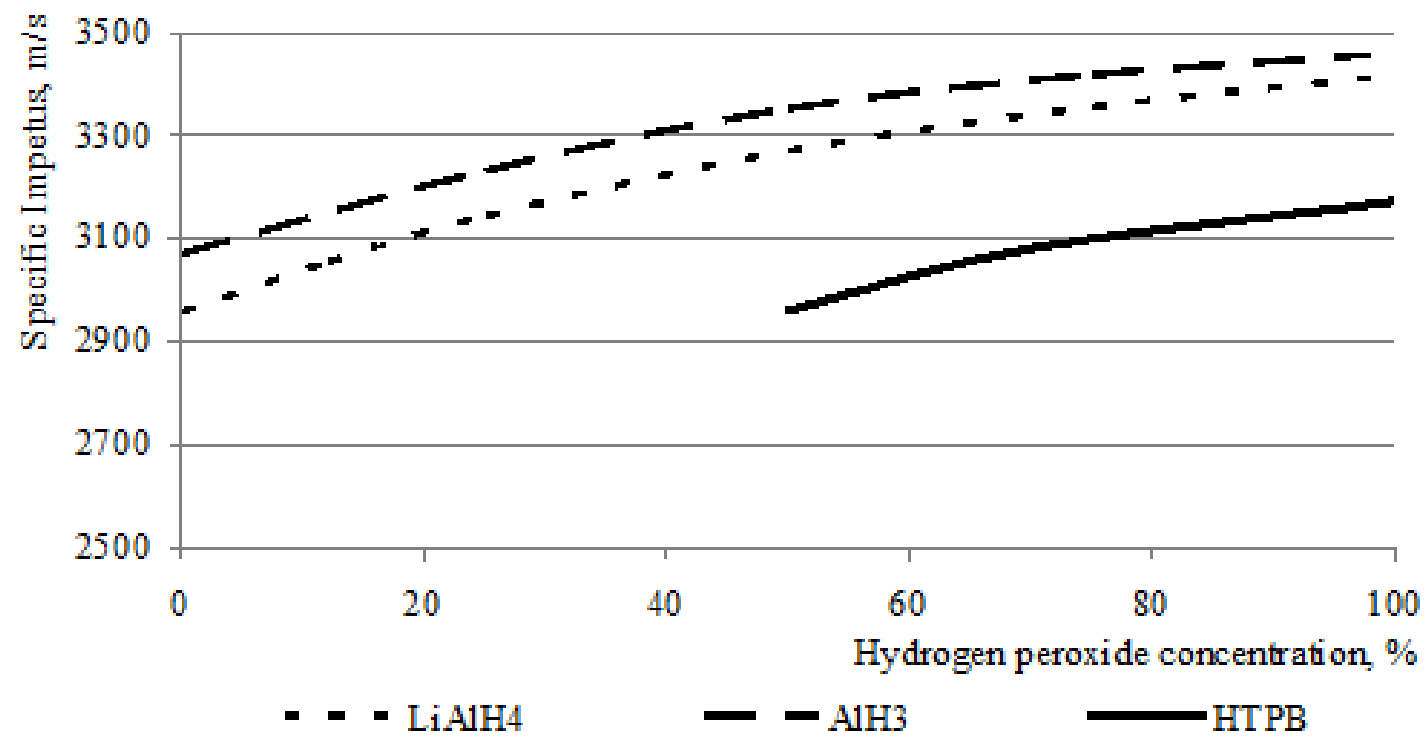

Pic. 2. Performance of hydrides with hydrogen peroxide

Therefore, one can make a conclusion on the use of lithium aluminum hydride and aluminum hydrides as fuels for:

- high-energy propulsion systems (in the propellant pair with 98\% HTP), with a specific impetus of up to $3,400 \mathrm{~m} / \mathrm{s}$;

- safer propulsion system (in pair with hydrogen peroxide of industrial grade or water), with a specific impulse of up to $3,000 \mathrm{~m} / \mathrm{s}$.

\subsection{Evaluation of propellant system parameters}

In additional to the typical challenges of hybrid rocket motors, i.e. combustion efficiency while minimizing their sizes, the challenges of the suggested propellant pairs include:

- hydride-based grain with minimum resin bond [11];

- for aluminized propellants - prevent aluminum oxide coagulation and sedimentation, and exclude carbon from a propellant pair.

Assessment of mass characteristics according to recommendations [8] let us specify the main characteristics of the propulsion system in $1.5 \mathrm{U}$ format, as a first approximation:

- propellants: commercial grade perhydrol $\left(35 \% \mathrm{H}_{2} \mathrm{O}_{2}\right) / \mathrm{Water}+\mathrm{LiAlH}_{4}$;

- specific impetus - 3,000 m/s $(2,550 \mathrm{~m} / \mathrm{s}$ for clean water);

- propellant mass fraction -0.50 ;

- total weight - $1.6 \mathrm{~kg}$;

- spacecraft delta velocity in $3 \mathrm{U}$ format, $4 \mathrm{~kg}-670 / 570 \mathrm{~m} / \mathrm{s}$. 


\subsection{Hydride feasibility insights}

The complexity and high costs of the synthesis and processing of hydrides and, as a result, high costs of products are a substantial impediment to their use on the earth. Nevertheless, they have found their niche in the areas where such application is justified from the technical point of view (propulsion systems of underwater objects, hydrogen storage facilities etc.).

The use of hydrides for micro and nano-satellites, with CubeSat launches worth of $\$ 40,000$ per kilo, suggests the attractive pattern. A certain increase in propellant costs (by $\$ 700$ per kilo for $50 \%$ of propellant mass fraction, i.e. by $1,8 \%$ ) is negligible if compared with the gains in energy characteristics (e.g. for $35 \% \mathrm{H}_{2} \mathrm{O}_{2} / \mathrm{LiAlH}_{4}$, a specific impetus grows by $13.2 \%$ in comparison with $\mathrm{N}_{2} \mathrm{O} / \mathrm{HTPB}$ ). Thus, the use of metal hydrides in nano-satellites propulsion systems is justified from the economic point of view.

\section{CONCLUSIONS}

The study demonstrates the expediency of further development of a nano-satellite hybrid propulsion system using aluminum hydride or lithium aluminum hydride as fuel in hybrid propellant with low-grade hydrogen peroxide as an oxidizer. Due to the high level of hydrogen in combustion products (over $60 \%$ ), the use of commercially produced peroxide grades $(35-50 \%)$ or even pure water as an oxidizer could provide high specific impetus at relatively low temperatures in a combustion chamber. In this case, the risks associated with potential explosions of highly concentrated hydrogen peroxide are significantly decreased, and in general, the safety of a propulsion unit increases.

As an additional benefit, the specific impetus of the proposed couple shows low sensitivity to a mixture ratio and concentration of hydrogen peroxide in an oxidizer.

As the next step of the research work, the study recommends the development and experimental work-out of a hybrid propulsion system based on a lithium aluminum hydride/35\% hydrogen peroxide couple.

\section{BIBLIOGRAPHY}

[1] Doncaster B., Williams C., Shulman J., 2017, “2017 Nano/Microsatellite market Forecast,” http:// spaceworksforecast.com/2017-market-forecast/

[2] James, K., et al., 2015,„Performance Characterization of the HYDROS ${ }^{\mathrm{T}}$ Water Electrolysis Thruster," Proceedings of the AIAA/USU Conference on Small Satellites, Logan, August 8-13, Paper No. SSC15-XI-5, pp. 1-7

[3] Orbital ATK, 2016, "Propulsion Products Catalog," https://www.orbitalatk.com/flight-systems/ propulsion-systems/docs/2016\%200A\%20Motor\%20Catalog.pdf

[4] Sawka W. and McPherson M., 2013, „Electrical Solid Propellants: A Safe, Micro to Macro Propulsion Technology," 49th AIAA/ASME/SAE/ASEE Joint Propulsion Conference, San Jose, July 14-17, Paper No. AIAA 2013-4168, pp. 1-21

[5] Dushku M. and Mueller P., 2012, „Additively Manufactured Propulsion System,” 26th Annular AIAA/USU Conference on Small Satellites, Logan, August 13-16, Paper No. SSC12-III-2, pp. 1-6

[6] Hybrid Rockets for CubeSats Project (HRC), 2015, NASA, https://techport.nasa.gov/view/91800

[7] Surmacz P., 2016, „Green Rocket Propulsion Research and Development at the Institute of Aviation: Problems and Perspectives", Journal of Kones Powertrain and Transport, Vol. 23, No. 1, pp. 337-344 
[8] Chiasson T. M, Lozano P. C., 2012, "Modeling the Characteristics of Propulsion Systems Providing Less Than 10 N Thrust,” M.S. thesis, http://ssl.mit.edu/publications/theses/SM-2012Chiasson Thomas.pdf

[9] Krivtsova V.I., 2000, The peculiarities of interactions with water of hydrogen containing hydro-reacting compositions at high pressures, International Journal of Hydrogen Energy, Volume 25, Issue 9, pp. 813-818

[10] Florczuk W., Rarata G., „Performance evaluation of hypergolic green propellants based on HTP for a future next generation spacecraft", 2017, 53rd AIAA/SAE/ASEE Joint Propulsion Conference, Atlanta, July 10-12

[11] Krivtsova V.I., 2001, The theoretical and experimental ways of creation of hydrogen storage and supply systems on the base of solid reagents for engines and power plants for flying vehicles, D.S. thesis, Zhukovsky National Aerospace University "Kharkov Aviation Institute"

\section{BEZPIECZNY I SKUTECZNY UKŁAD NAPĘDOWY DLA NANOSATELITÓW}

\section{Streszczenie}

Podjęto wiele prób opracowania układów napędowych dla statku kosmicznego z klasy nanosatelitów, aby zapewnić możliwość manewrowania na orbicie. W szczególności jednym z obiecujących typów układów napędowych dla paliwa chemicznego jest układ hybrydowy. W artykule zaproponowano warianty kompozycji pędnych z wodorkiem metalu jako paliwem, które można wybrać dla hybrydowego napędu nanosatelitarnego. Zaprezentowano główne wymagania dotyczące układów napędowych dla paliwa chemicznego do nanosatelitów, i przedstawiono potencjalne pary propelentów oparte na zwartym wodorku metalu jako paliwie. Określono główne właściwości techniczne układu napędowego dla satelitów klasy CubeSat $1 \mathrm{U}$.

Słowa kluczowe: napęd satelitarny, wodorek metalu, nadtlenek wodoru. 